\title{
INTERTEXTUALIDAD Y METAPOESÍA EN LA PRIMERA ETAPA DE LA POESÍA DE PERE GIMFERRER
}

José Luis REY

I. E. S. Manuel Reina (Puente Genil)

$\mathrm{L}$

a primera etapa de la poesía de Pere Gimferrer, escrita en español, se extiende entre 1962 y 1969, según lo estudié en mi tesis doctoral titulada Caligrafía del fuego. La poesía de Pere Gimferrer (Rey, 2005). Esta etapa supone la eclosión en el panorama de la poesía de posguerra de una voz única y distinta, que cambiaría, junto con sus compañeros de generación, el curso de la poesía hispánica. Aunque oficialmente dicha etapa comienza con Arde el mar, hay dos libros anteriores a éste, Malienus y Mensaje del tetrarca, que ya establecen las claves de una poética estéticamente revolucionaria ${ }^{1}$. Ya en Malienus, saludado efusivamente por Vicente Aleixandre, se hace patente la presencia de una tradición europea y universal. Estamos ante un poema largo, dividido en fragmentos, que crea una atmósfera propia y donde se hace presente la influencia principal del poeta Saint-John Perse:

\footnotetext{
Qué os diré de su estirpe dinastía de halcones lean otros en ella qué de su claro aliento se resisten mis manos no misión no cumplida con el mandato llega hasta mí un mensajero
}

El mundo mítico y simbólico de Perse, así como su orientación hímnica, está muy presente en estos dos libros iniciales del poeta catalán. El fulgor de las imágenes, la creación o evocación de un orbe primigenio, el tono celebratorio, todo ello aproxima esta primera poesía gimferreriana a la obra del Nobel de lengua francesa. Y ello va acompañado de una reflexión sobre la función misma de la poesía, como capacidad genesíaca de elevación de un orden autónomo: y las nubes que instauran su incendiado delirio / sobre los estertores del imperio terrestre.

\footnotetext{
${ }^{1}$ Sigo para este artículo la siguiente edición: P. Gimferrer, Poemas 1962-1969, Visor, Madrid, 1988. Todos los versos citados del autor proceden de esta edición.
} 
Mensaje del tetrarca, en concreto, se abre con dos citas, una de Ercilla y otra de Perse. Ambas dejan clara la aspiración épica de estos poemas primerizos y sin embargo ya logrados. Una épica metapoética que describe la fundación, prosperidad y decadencia del reino de la palabra lírica. Si en lo temático, como decimos, esta poesía está cerca de Perse, en lo formal hay una influencia muy curiosa de Claudio Rodríguez, ya que Mensaje del tetrarca está redactado en romance endecasilábico, como el claudiano Don de la ebriedad. Así, encontramos también que el impulso rítmico de Rodríguez es homenajeado y seguido en Mensaje del tetrarca desde una estética bien distinta, pero que coincide con la luminosidad y la entrega hímnica del poeta de Zamora, como se ve en estos versos gimferrerianos:

\footnotetext{
Tolvanera perdida, ventisquero disuelto en noche, asunto ya del aire. Palafrenero, la ciudad se acerca. Dedos de plomo empañan los cristales. Así se vive, así día tras día sabemos que la muerte está en la calle.
}

Así pues, Perse como fondo y Claudio Rodríguez como forma son las dos principales referencias intertextuales en la obra primeriza de Gimferrer. Pasemos ahora al libro que lo cambió todo, Arde el mar, de 1966. Desde el primer poema, Mazurca en este día, observamos la importante presencia en el libro de los planteamientos teóricos y la práctica poética de T. S. Eliot y Ezra Pound. La yuxtaposición de distintos momentos temporales, el afán por demostrar la caída del tiempo mítico en un tiempo cotidiano y banal, las referencias culturales, etc., son elementos que remiten al Eliot de The Waste Land sobre todo, aunque también al Pound de The Cantos. Todo ello es muy visible y así lo ha señalado la crítica. Lo que ya no parece tan visible es el fondo mallarmeano de Arde el mar y esto tiene que ver, más que con las referencias formales del libro, con su sentido metapoético. Al igual que Mallarmé creó el principal agujero negro en la galaxia de la poesía europea, Gimferrer crea en Arde el mar un espacio de destierro verbal donde el sujeto lírico agoniza en la perfección de un mundo sellado y ya hecho e inaccesible como un castillo kafkiano. Tras la fundación del espacio poético emprendida por Góngora y culminada por la modernidad, coronado gloriosamente dicho espacio con la presencia del dios deseado y deseante de Juan Ramón Jiménez, a Gimferrer le tocó relatar el exilio de dicho espacio verbal y para ello sigue a Mallarmé:

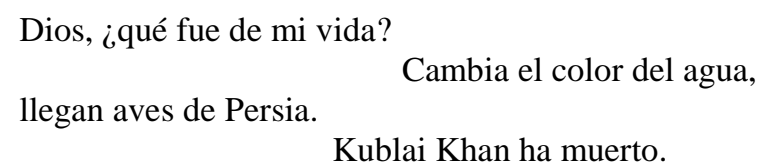

Versos míticos ya los señalados, donde no solo muere el Khan de Coleridge, sino también agoniza el sujeto en un espacio poético que no puede ya albergar vida. Y en esto coincide 
el poeta catalán con otro gran poeta de su generación, Guillermo Carnero, aunque en éste último la desolación es aún mayor. Mallarmé había puesto la gloria de su proyecto lírico, paradójicamente, en el fracaso del mismo; en la imposibilidad de la poesía para sobrevivir como orbe autónomo que alberga vida, tal como es el espacio exterior del mundo. Estoy hechizado: jel azur, el azur!, nos había dicho el poeta francés. Del mismo modo, Gimferrer está hechizadamente desterrado de su propia palabra poética. Todo ello se comprueba fácilmente en el poema emblemático del libro, la Oda a Venecia ante el mar de los teatros, que supone una curiosa relectura y refutación del Wordsworth de la Oda a la inmortalidad, en cuyos versos el poeta inglés volvió a fundar el mito de la Caída del hombre: una gloria se ha ido de la tierra. Wordsworth nos dice que hemos de seguir adelante, esperanzadamente, aunque hayamos perdido el esplendor de la infancia. Pues bien, la Oda gimferreriana no relata la Caída del hombre, sino la Caída del artista, del poeta. En efecto, una gloria se ha ido de la tierra del verbo:

\section{Es doloroso y dulce \\ haber dejado atrás la Venecia en que todos para nuestro castigo fuimos adolescentes}

Se puede seguir viviendo en la vida, como demuestra Wordsworth, pero aquel que ha conocido el paraíso poético está destinado a perderlo, como indica Gimferrer. Así, Arde el mar se convierte en la gran elegía estética del exilio de un paraíso verbal inaccesible ya al poeta y que éste debe abandonar. Refutación de Wordsworth, ratificación de Mallarmé, Arde el mar presenta, como se ha dicho, una galería de recursos eliotianos que se evidencian, por ejemplo, en los poemas Himno y Canto. Ulises y Teseo, máscaras respectivas del poeta mismo en dichos poemas, son figuras que, como el Tiresias de Eliot, hacen contrastar el sublime universo mítico con la degradación contemporánea. En este caso, la degradación es la imposibilidad de vivir en el espacio del poema. La isla de Circe, donde Ulises es pasajero, es la isla del texto, la isla del arte. Pero Ulises, como el poeta, ha de abandonarla. Teseo, en el laberinto, comprueba a su vez que el arte ofrece permanencia, pero no vida. Y no solo influencias poéticas hay; también filosóficas. Wittgenstein está muy presente en el planteamiento teórico de Arde el mar; en verdad, podríamos decir que este libro gimferreriano es la comprobación poética de las proposiciones de su Tractatus. El arpa en la cueva, último poema del libro, parece situarse también en la más famosa frase wittgensteiniana: de lo que no se puede hablar hay que callar. La atmósfera de este poema recuerda al cuento Casa tomada, de Julio Cortázar. Hay en ambos una amenaza misteriosa que nos obliga a retirarnos hacia el interior del texto, hacia el espacio poético como refugio ante el avance ominoso de la realidad. Pero, también en el texto, los duendes acabarán entrando por la chimenea.

En La muerte en Beverly Hills (1968) la principal influencia que ha señalado la crítica es la del cine negro norteamericano. Y es cierta esa presencia en el plano 
Tropelías. Revista de Teoría de la Literatura y Literatura Comparada, 20 (2013) 47 Intertextualidad y metapoesía en la primera etapa de la poesía de Pere Gimferrer

argumental del libro, pero su fondo es, otra vez, metapoético y remite a Mallarmé por las razones ya citadas. Este poema dividido en fragmentos se constituye como una hermosa elegía del sujeto poético, consciente de su fugacidad en el espacio que él mismo ha construido: Yo que fundé todos mis deseos/ bajo especies de eternidad/vero alargarse al sol mi sombra en julio. La gran diferencia con Arde el mar reside en que este libro es la elegía del espacio poético, mientras La muerte en Beverly Hills es la elegía del sujeto lírico, un sujeto fantasmagórico, múltiple, enmascarado, que muere y resucita, que aparece y desaparece. Para ello Gimferrer sigue el procedimiento del montaje cinematográfico y lo hace coincidir con la yuxtaposición eliotiana. Otra presencia importante aquí es la de Lorca, con el cual no se coincide solamente respecto a la atmósfera americana del poema, sino también en el uso del versículo visionario. Como en Novalis, la noche que reina en el poema es necesaria por su valor de semilla de la luz. Y el amor que constituye el tema aparente del texto (pues su tema real, como vemos, es la soledad del sujeto poético y su imposibilidad de vivir en el poema) recuerda al amor intransitivo de las Elegías de Rilke o al amor como destrucción aleixandrino. Por otra parte, en esta desolada realidad del poema como orbe autónomo negado ya al sujeto, frente a la estación florida de Góngora, principio de autonomía que es ya insuficiente, aquí empieza a hacer frío y las muchachas rubias se miran temblando en los escaparates, escaparates que remiten al mismo artificio verbal, capaz de reflejar al sujeto, pero incapaz de salvarlo.

Finalmente, de "Extraña fruta" y otros poemas (sin edición exenta e incluido en el volumen citado que reúne la primera etapa castellana) es el tercer gran libro de este primer período de la poesía gimferreriana. Frente al carácter elegíaco de los libros anteriores, esta obra es un libro epifánico. Aquí no se relata el exilio del espacio poético ni la soledad del sujeto lírico, sino el momento justo de la creación poética, el país de la blancura, en el que coinciden, por un instante, la experiencia vital y el afán de transformarla en arte. Poe, Stevenson, Bach, Billie Holiday, Verne y otros artistas son homenajeados aquí. Gimferrer encuentra incluso un lugar para la reflexión sobre su propia obra, en el poema más curioso de la recopilación, el titulado Arde el mar:

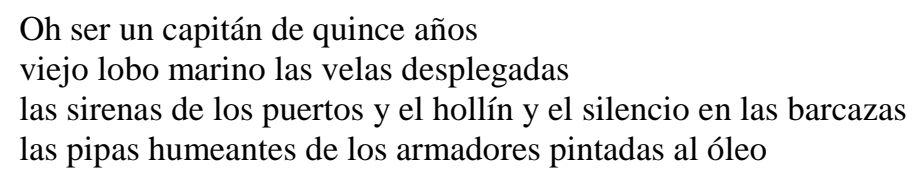

Es uno de los poemas más interesantes del libro y también uno de los más entusiastas de toda la obra del autor. Este entusiasmo reside en la condición del texto como epifanía, en recordar el inicio de la creación del mundo verbal sin que aún ese mundo se nos imponga. Poemas como éste son centrales en la obra de Gimferrer, pues recuerdan que la grandeza no es el canto logrado y autónomo, sino el hecho mismo de 
cantar. La aventura de la creación es lo que canta Extraña fruta. Así pues, ¿cómo no ver aquí la presencia tutelar y órfica del gran Rimbaud, el muchacho de Charleville que tenía aquellos arranques hímnicos? También pensamos en Keats, con su impulso ascensional. O en el mejor y más celebratorio Rilke. Una poesía de carácter hímnico que celebra la poesía misma, el hecho de cantar, es lo que encontramos en Extraña fruta.

No debo extenderme más. Baste lo señalado para afirmar como cierre que de la gran calidad de la obra toda de Gimferrer, que sigue gozosamente en marcha, deviene una fe inquebrantable en la palabra poética. Si por su conciencia de la modernidad y la tradición heredada, Gimferrer vive en el día después del Edén, expulsado del paraíso verbal, ello no obsta para que, en las siguientes etapas, como se ve en su reciente libro Alma Venus, esta fe le haga cantar las cimas y visiones de la poesía misma, que le fue concedida en todo su esplendor a un poeta nacido en Barcelona en el año 1945.

\section{Bibliografía}

GIMFERRER, Pere (1988): Poemas 1962-1969, Visor, Madrid.

REY, José Luis (2005): Caligrafía del fuego. La poesía de Pere Gimferrer (1962-2001), Pre-textos, Valencia. 